\title{
JUSTYNA GoŹDZIEWICZ-BIECHOŃSKA
}

\section{Z prawnej problematyki ochrony krajobrazu na obszarach wiejskich}

1. Współczesne szerokie zainteresowanie społeczne problematyką ochrony krajobrazu wiejskiego wynika przede wszystkim z dwóch tendencji. Z jednej strony zauważane jest zjawisko narastającego chaosu funkcjonalnego i wizualnego, co skutkuje krytycznym stanem przestrzeni w Polsce ${ }^{1}$. Dotyczy to również obszarów wiejskich, które stanowią wszak 93,1\% powierzchni kraju². Niewątpliwie krajobraz wiejski, jako zjawisko dynamiczne, podlega nieustannym zmianom. Nasilenie ich w ostatnim w czasie, w szczególności związanych z globalizacją i urbanizacją, wskazuje jednak, że obecnie trwa jeden z okresów najbardziej radykalnych przemian krajobrazu w historii ${ }^{3}$. Jednocześnie zaobserwować można coraz silniejszą obecność toposu wiejskości ujmowanej w kategoriach bukolicznych i nostalgicznych. Krajobraz jako istotny element dziedzictwa kulturowego wsi został uznany za wartość, szczególnie w obliczu tendencji do jego przemijania i zagrożenia degradacją ${ }^{4}$.

Należy przy tym zauważyć swoisty paradoks relacji człowieka z krajobrazem. Jest on wytworem działalności ludzkiej, posiadającym nieraz unikatową wartość kulturową i przyrodniczą. Ten aspekt nabiera zna-

${ }^{1}$ Polska polityka architektoniczna. Polityka jakości krajobrazu, przestrzeni publicznej, architektury, projekt zespołu autorskiego pod red. K. Chwaliboga, Warszawa 2011, www.sarp.org. pl/pliki/ppa.pdf, s. 9.

2 Dane na podstawie II Projektu Programu Rozwoju Obszarów Wiejskich 2014-2020 (PROW 2014-2020) z 24 stycznia 2014 r., https://www.minrol.gov.pl/pol/Wsparcie-rolnictwa-irybolowstwa/PROW-2014-2020.

${ }^{3}$ M. Antrop, Why Landscapes of the Past are Important for the Future, „Landscape and Urban Planning" 2005, nr 70, s. 25.

${ }^{4}$ E. Raszeja, Interpretacja krajobrazu wiejskiego - między teoriq a praktykq, ,Czasopismo Techniczne. Architektura" 2007, z. 5-A, s. 75. 
czenia w odniesieniu do polskich obszarów wiejskich, których wysoki poziom bioróżnorodności i walory środowiskowe wyróżniają się na tle innych państw Unii Europejskiej ${ }^{5}$. Jednocześnie jednak człowiek stanowi największe zagrożenie dla stanu krajobrazu i to właśnie ochrona przed negatywnym oddziaływaniem antropogenicznym jest przedmiotem regulacji prawnej. Wobec powyższych zjawisk przed współczesnym ustawodawcą stoi trudne zadanie stworzenia skutecznego systemu ochrony krajobrazu, który będzie uwzględniał jego złożoność i wieloaspektowość.

Przedmiotem niniejszego opracowania jest ochrona krajobrazu na obszarach wiejskich. Podjęcie tej tematyki badawczej na gruncie nauk prawnych uzasadniają zarówno względy poznawcze, jak i praktyczne. Wobec wspomnianych radykalnych przemian stanowi bowiem ona nowe wyzwanie badawcze, wymagające uwzględnienia współczesnych paradygmatów rozwojowych obszarów wiejskich. Co więcej, swoistość pola badawczego - obszarów wiejskich wymaga odrębnego ujęcia ze względu na nieadekwatność metod naukowych i instrumentów ochronnych charakterystycznych dla podejścia urbanistycznego. Ponadto nadanie mu rangi konstytucyjnej w ustawach zasadniczych niektórych państw europejskich potwierdza wagę tego zagadnienia ${ }^{6}$. Ochrona krajobrazu, w tym wiejskiego, w Polsce nadal napotyka szereg trudności, nie tylko w wymiarze funkcjonowania systemu prawnego, lecz także $\mathrm{w}$ aspekcie tworzenia i zmiany jego podstaw normatywnych, o czym świadczą chociażby omówione poniżej ostatnie działania legislacyjne w tym zakresie.

Celem niniejszego artykułu jest próba odpowiedzi na pytanie, w jakim stopniu regulacja normatywna zapewnia skuteczną ochronę krajobrazu na obszarach wiejskich. Realizacja tak sformułowanego celu wymaga już na wstępie określenia prawnego pojęcia krajobrazu wiejskiego, a także uwzględnienia w rozważaniach najnowszego projektu tzw. ustawy krajobrazowej.

${ }^{5}$ Zob. np. D. Wascher, B. Pedroli, Blueprint for EUROSCAPE 2020. Reframing the Future of the European Landscape. Policy Visions and Research Support, May 2008, www.landscapeeurope.net, s. 17.

${ }^{6}$ Problematyce krajobrazu nadano rangę konstytucyjną we Włoszech, Szwajcarii, Niemczech i Portugalii (zob. E. Raszeja, Ochrona krajobrazu w procesie przekształceń obszarów wiejskich, Poznań 2013, s. 111). Szczególnie istotne miejsce zajmuje ochrona krajobrazu w ustawodawstwie włoskim, problematyka ta budzi też szerokie zainteresowanie doktryny i orzecznictwa (zob. K. Szuma, Prawne aspekty ochrony krajobrazu w ustawodawstwie włoskim, „Prawo i Środowisko" 2013, nr 1, s. 85-95). 
Problematyka krajobrazowa stanowi przedmiot zainteresowania wielu dyscyplin nauki, stąd literatura przedmiotu jest bogata ${ }^{7}$. Również w naukach prawnych temat ten był podejmowany, lecz opracowania miały raczej charakter przyczynkowy i fragmentaryczny ${ }^{8}$. Jeszcze rzadziej kwestie te poruszane były w odniesieniu do terenów wiejskich ${ }^{9}$. Ze względu na złożoność i wieloaspektowość podejmowanej problematyki niniejsze opracowanie ma charakter wstępny i zawiera sygnalizację problemów badawczych oraz wyznaczenie kierunków dalszych poszukiwań.

2. Punktem wyjścia rozważań jest określenie pojęcia krajobrazu oraz jego szczególnego rodzaju - krajobrazu wiejskiego. Powstaje bowiem istotne pytanie, co stanowić ma przedmiot ochrony ${ }^{10}$. Odpowiedź na nie napotyka jednak szereg trudności wynikających z tego, że krajobraz jest obiektem badań wielu dyscyplin naukowych, posługujących się własnymi paradygmatami i metodologią. W naukach przyrodniczych ${ }^{11}$ (w tym przede wszystkim w ekologii krajobrazu i geografii fizycznej) dominują ujęcia ilościowe i obiektywizujące. $Z$ kolei nauki humanistyczne i społeczne (psychologia środowiskowa, filozofia, geografia humanistyczna, behawioralna i socjologia) skupiają się na badaniu doświadczenia przestrzeni i miejsc przez jednostki i społeczności. Nauki stosowane (wśród nich architektura, urbanistyka i planowanie krajobrazu) analizują to zjawi-

${ }^{7}$ Zob. np. przegląd literatury w: E. Raszeja, Ochrona..., s. 62 i n.; I. Niedźwiedzka-Filipiak, Wyróżniki krajobrazu i architektury wsi Polski poludniowo-zachodniej, Wrocław 2009, s. 13 i n.; J.-E. Kim, S.-K. Hong, N. Nakagoshi, International Trends of Rural Landscape Researches for Land Management and Policies, w: S.-K. Hong et al., (red.), Landscape Ecological Applications in Man-Influenced Areas: Linking Man and Nature Systems, Dordrecht 2007, s. 489-492.

${ }^{8}$ Należy wskazać tu przede wszystkim następujące prace: J. Boć, W sprawie pojęcia prawnej ochrony krajobrazu, ,Acta Universitatis Wratislaviensis, nr 458, „Przegląd Prawa i Administracji XII”, Wrocław 1979; W. Brzeziński, Ochrona prawna krajobrazu, w: L. Bar (red.), Studia z dziedziny prawa administracyjnego, Wrocław 1971; H. Olbrycht, Prawo człowieka do krajobrazu, w: J. Sommer (red.), Prawo czlowieka do środowiska naturalnego, Wrocław 1987; T. Bąkowski, Ochrona krajobrazu w prawie zagospodarowania przestrzennego, „Prawo Administracja - Kościół” 2006, nr specjalny 26.

${ }^{9}$ Zob. A. Król, Prawna ochrona krajobrazu wiejskiego w kontekście integracji europejskiej, ,Samorząd Terytorialny” 2000, nr 10, s. 55-57

${ }^{10} \mathrm{~J}$. Boć stwierdza, że efektywne wyróżnienie przedmiotu ochrony (kształtowania) krajobrazu stanowi jeden z najtrudniejszych zabiegów pojęciowych w sferze problematyki ochrony środowiska naturalnego (idem, op. cit., s. 65).

${ }^{11}$ Zob. np. U. Myga-Piątek, Spór o pojęcie krajobrazu w geografii i dziedzinach pokrewnych, „Przegląd Geograficzny” 73, 2001, z. 1-2, s. 163-176; A. Richling, J. Solon, Ekologia krajobrazu, Warszawa 2011, s. 18-21. 
sko $\mathrm{w}$ aspekcie formalnym i kompozycyjnym w celu identyfikacji, interpretacji i oceny przydatnej do twórczego kształtowania krajobrazu. Uzasadnione jest zatem twierdzenie, że problematyka ta ma charakter interdyscyplinarny ${ }^{12}$.

Pojęcie krajobrazu na gruncie nauk prawnych opiera się na zapożyczeniach z innych dziedzin, przy czym tradycyjnie wyróżnia się wśród nich dwie koncepcje ${ }^{13}$ : biologiczną (geograficzno-biologiczna), w której rozumie się go jako przyrodę wraz z elementami antropogenicznymi na naturalnie ograniczonym odcinku ziemi, oraz fizjonomiczną (architektoniczna), w której krajobraz stanowi fizjonomię powierzchni ziemi będącą syntezą części przyrodniczych i kulturowych. To ostatnie ujęcie znajduje odzwierciedlenie w regulacjach prawnych.

Prawodawca polski posługuje się tym terminem w wielu aktach normatywnych, lecz nie formułuje jego definicji legalnej. Krajobraz jest wskazany jako element środowiska w definicji zawartej w art. 3 pkt 39 ustawy z 27 kwietnia 2001 r. - Prawo ochrony środowiska ${ }^{14}$. Z kolei ustawa z 16 kwietnia 2004 r. o ochronie przyrody ${ }^{15}$ używa tego terminu $\mathrm{w}$ definicji środowiska przyrodniczego ${ }^{16}$, zawiera ona również definicję walorów krajobrazowych ${ }^{17}$, a także wymienia krajobraz pośród zasobów, tworów i składników przyrody podlegających ochronie (art. 2). Definicja krajobrazu kulturowego występuje natomiast w ustawie z 23 lipca 2003 r. o ochronie zabytków i opiece nad zabytkami ${ }^{18}$. Z kolei zgodnie $\mathrm{z}$ art. 1 ustawy o planowaniu i zagospodarowaniu przestrzennym ${ }^{19} \mathrm{~W}$ planowaniu

${ }^{12}$ Zob. np. M. Kistowski, Koncepcja krajobrazu przyrodniczego i kulturowego w planach zagospodarowania przestrzennego województw, w: A. Zaręba, D. Chylińska (red.), Studia krajobrazowe jako podstawa właściwego gospodarowania przestrzenia, Wrocław 2008, s. 12; E. Raszeja, Ochrona ..., s. 62 i n.

${ }^{13}$ Zob. m.in. H. Olbrycht, op. cit., s. 96-98; M. A. Król, op. cit., s. 55-57; T. Bąkowski, op. cit., s. 33-34 i literatura tam wskazana.

${ }^{14}$ Dz. U. 2013, poz. 1232 ze zm.

${ }^{15}$ T.jedn.: Dz. U. 2013, poz. 627 ze zm.

${ }^{16}$ Środowisko przyrodnicze - krajobraz wraz z tworami przyrody nieożywionej oraz naturalnymi i przekształconymi siedliskami przyrodniczymi z występującymi na nich roślinami, zwierzętami i grzybami (art. 5 pkt 20 ustawy o ochronie przyrody).

${ }^{17}$ Wartościami krajobrazowymi są wartości ekologiczne, estetyczne lub kulturowe obszaru oraz związane z nim rzeźba terenu, twory i składniki przyrody, ukształtowane przez siły przyrody lub działalność człowieka (art. 5 pkt 23 ustawy o ochronie przyrody).

${ }^{18}$ Dz. U. 2003, Nr 162, poz. 1568 ze zm. Zgodnie z art. 3 pkt 14 tej ustawy krajobraz kulturowy oznacza ,przestrzeń historycznie ukształtowaną w wyniku działalności człowieka, zawierającą wytwory cywilizacji oraz elementy przyrodnicze".

${ }^{19}$ T.jedn.: Dz. U. 2012, poz. 647 ze zm. 
i zagospodarowaniu przestrzennym uwzględnia się zwłaszcza wymagania ładu przestrzennego oraz walory architektoniczne i krajobrazowe. Przytoczone powyżej definicje normatywne potwierdzają, że w polskim prawodawstwie funkcjonuje pojęcie krajobrazu oparte na koncepcji fizjonomicznej ${ }^{20}$.

Poza wskazanymi uprzednio aktami prawnymi termin „krajobraz” oraz problematyka jego ochrony występują w Europejskiej konwencji krajobrazowej $^{21}$, która mocą ratyfikacji z 21 września 2005 r. została włączona do polskiego porządku prawnego ${ }^{22}$. Traktat ten należy to tzw. miękkiego prawa międzynarodowego, a środki ochrony w nim przewidziane mają raczej charakter edukacyjny niż restrykcyjny ${ }^{23}$. Co istotne, akt ten zawiera systemowe ujęcie krajobrazu i jego ochrony, a ponadto jego zapisy odzwierciedlają współczesne, wieloaspektowe pojmowanie krajobrazu w nauce i są znamienne dla kierunków rozwoju współczesnego międzynarodowego prawa ochrony środowiska ${ }^{24}$.

Zgodnie z art. 1 Konwencji, krajobraz stanowi ,znaczny obszar, postrzegany przez ludzi, którego charakter jest wynikiem działania i interakcji czynników przyrodniczych i/lub ludzkich". Z kolei przez ochronę krajobrazu rozumie się, ,działania na rzecz zachowania i utrzymywania ważnych lub charakterystycznych cech krajobrazu tak, aby ukierunkować i harmonizować zmiany, które wynikają z procesów społecznych, gospodarczych i środowiskowych". Na podstawie przytoczonych definicji wyróżnia się następujące aspekty pojęcia krajobrazu: antropocentryzm, dynamizm i interakcję ${ }^{25}$. Antropocentryzm przejawia się w tym, że ludzka multisensoryczna percepcja kreuje krajobraz, który istnieje tylko w relacji

${ }^{20}$ Por np. T. Bąkowski, op. cit., s. 35; M. A. Król, op. cit., s. 56.

${ }^{21}$ Europejska konwencja krajobrazowa sporządzona we Florencji 20 października 2000 r., ratyfikowana przez Polskę 21 września 2005 r., Dz. U. 2006, Nr 14 poz. 98 (dalej jako: Konwencja).

${ }^{22}$ Należy zauważyć, że judykatura, wypowiadając się co do charakteru prawnego Europejskiej konwencji krajobrazowej, uznała, że nie nadaje się ona do bezpośredniego stosowania (zob. wyrok WSA w Warszawie z 15 kwietnia 2008 r., IV SA/Wa 194/08, Lex, nr 516729).

${ }^{23}$ Por. J. Ciechanowicz-McLean, Europejska konwencja krajobrazowa, „Prawo i Środowisko" 2006, nr 2, s. 78-84.

${ }^{24} \mathrm{~W}$ międzynarodowym prawie ochrony środowiska zauważyć można ewolucję koncepcji ochrony przyrody od ochrony zachowawczej i restytucyjnej w kierunku zrównoważonego korzystania z różnorodności biologicznej. Konsekwencją tego jest rozszerzenie ochrony z obiektowej również na siedliskową i obszarową. Zob. J. Ciechanowicz-McLean, w: J. Ciechanowicz-McLean (red.), Polskie prawo ochrony przyrody, Warszawa 2006, s. 18-27.

${ }^{25}$ Zob. np. E. Raszeja, Ochrona..., s. 66-67. 
z odbiorca - człowiekiem. W aspekcie drugim krajobraz stanowi wynik ciagłego procesu formowania, kształtowania. Wreszcie jego interakcyjny charakter wynika z ujmowania krajobrazu jako efektu związków i oddziaływań czynników naturalnych oraz kulturowych.

W Konwencji krajobraz rozumiany jest zatem holistycznie - jako wspólne dziedzictwo, cały obszar otaczający człowieka - jego miejsce życia podlegające ciagłym zmianom wynikającym z procesów społecznych, gospodarczych i środowiskowych ${ }^{26}$. Przy czym pojęcie to nie jest budowane na kryterium jakościowym, odnosi się bowiem zarówno do krajobrazu wyjattkowego, jak i pospolitego i zdegradowanego. Ochrona krajobrazu $\mathrm{w}$ omawianym traktacie, przez powiązanie $\mathrm{z}$ gospodarowaniem nim i jego planowaniem, nabiera charakteru czynnego, kształtującego (obejmującego również powiększenie, odtworzenie lub utworzenie), nieograniczonego jedynie do aktywności konserwatorskiej. Przez gospodarowanie rozumie się bowiem w Konwencji działanie z perspektywy trwałego i zrównoważonego rozwoju, planowanie zaś oznacza skuteczne działanie perspektywiczne mające na celu powiększenie, odtworzenie lub utworzenie krajobrazów. Gospodarką przestrzenną jest więc dynamiczne zarządzanie krajobrazem powiązane z planowaniem przestrzennym i architekturą krajobrazu, co w połączeniu z jego ochroną daje zintegrowany i pełny system ochrony i kształtowania w rozumieniu Konwencji.

Przedstawione powyżej ujęcie krajobrazu, zawarte w Europejskiej konwencji krajobrazowej i zgodne ze współczesnym holistycznym rozumieniem jego w nauce, pozwala na wyznaczenie pojęcia krajobrazu wiejskiego przez powiązanie z zagadnieniem obszarów wiejskich, a w szczególności z ich delimitacją. Termin „obszary wiejskie” nie posiada jednak ustalonej, jednolitej definicji ani w prawodawstwie, ani w dyskursie naukowym $^{27}$. Ponadto każda $\mathrm{z}$ dziedzin zajmujących się tą problematyką ujmuje go z różnych perspektyw ${ }^{28}$.

${ }^{26}$ Takie ujęcie zbieżne jest $\mathrm{z}$ rozwijającym się w ostatnich dziesięcioleciach podejściem badawczym, w którym krajobraz stanowi syntezę środowiska przyrodniczego i kulturowego (B. Żarska, Ochrona krajobrazu, Warszawa 2011, s. 12).

${ }^{27} \mathrm{P}$. Cloke wyodrębnia dwa podejścia badaczy zajmujących się problematyką wiejską w kwestii wyznaczania zakresu pojęciowego swoich badań. Pierwsze odrzuca możliwość zdefiniowania „wiejskości” ze względu na wewnętrzne skomplikowanie tego pojęcia i jego zewnętrzną zbieżność z pokrewnymi terminami, takimi jak gmina, osadnictwo, przeznaczenie terenu. W rezultacie wszelkie próby definiowania tego pojęcia są bezcelowe i nieprzydatne. Drugie podejście badawcze zakłada, że przyjęcie definicji w tym względzie, jakkolwiek niedoskonałej, jest niezbędnym pierwszym krokiem do ukazania podobieństw i różnic pomiędzy 
Skoro zatem nie można sformułować uniwersalnej definicji obszaru wiejskiego, można za J. Bańskim opisać obszary wiejskie przez wyróżnienie następujących ich cech: swoisty otwarty krajobraz, stosunkowo niska gęstość zaludnienia, przewaga ludności związanej z gospodarką rolną i leśną, tradycyjny styl życia (bliski naturze) i zwyczaje, ekstensywne użytkowanie ziemi (przede wszystkim rolnicze i leśne), rzadka zabudowa i rozproszone osadnictwo, większość mieszkańców uważa, że mieszka na $\mathrm{wsi}^{29}$. Należy wreszcie zauważyć, że problematyka krajobrazowa stanowi istotny element definiowania obszaru wiejskiego zarówno na gruncie badań naukowych, jak i w rozumieniu potocznym, w którym konstytuuje najistotniejszą cechę opisową tego terminu ${ }^{30}$.

Poza definicjami naukowymi odrębne rozumienie obszarów wiejskich przyjmują organizacje międzynarodowe oraz podmioty zajmujące się polityką przestrzenna, planowaniem strategicznym, a także gromadzeniem danych statystycznych. Różne są też kryteria, na których opiera się określenie obszarów wiejskich w tych materiałach. Według metodologii Organizacji Gospodarczej i Rozwoju (OECD) obszarem wiejskim jest teren, na którym ponad $50 \%$ populacji mieszka $\mathrm{w}$ gminach wiejskich. Do tych ostatnich należą zaś te, które posiadają gęstość zaludnienia do $150 \mathrm{osób} / \mathrm{km}^{2}$.

Definicja OECD została też zaproponowana państwom członkowskim przez Komisję Europejską w ramach unijnej polityki obszarów wiejskich na potrzeby regionalnych programów rozwoju obszarów wiejskich (PROW), jednakże została ona przyjęta jedynie w nielicznych krajowych i regionalnych PROW ${ }^{31}$. Ponadto $\mathrm{w}$ analizach i publikacjach Unii Euro-

obszarami miejskimi i wiejskimi (P. Cloke, An Introduction to Rural Settlement Planning, Routledge 2013, s. 9-12).

${ }^{28}$ Zob. np. analizę koncepcji obszaru wiejskiego w badaniach geograficznych: J. Bański, Wieś w badaniach geograficznych - ewolucja badań i przeglad koncepcji obszaru wiejskiego, w: M. Halamska (red.), Wieś jako przedmiot badań naukowych na poczqtku XXI wieku, Warszawa 2011, s. 29-44.

${ }^{29}$ J. Bański, op. cit., s. 41.

${ }^{30} \mathrm{Z}$ badań ankietowych przeprowadzonych przez K. Halfacree w dystrykcie Lancaster wynika, że największa część respondentów (68\%) kojarzy pojęcie obszaru wiejskiego z otwartym niezabudowanym krajobrazem (K. H. Halfacree, Talking about Rurality: Social Representations of the Rural as Expressed by Residents of Six English Parishes, „Journal of Rural Studies” 11, 1995, nr 1, s. 1-20).

${ }^{31}$ Problem definiowania i uwzględniania obszarów wiejskich w PROW państw członkowskich był przedmiotem analizy tematycznej grupy roboczej nr 1 utworzonej w 2009 r. pod przewodnictwem Komisji Europejskiej (Dyrekcji Generalnej ds. Rolnictwa i Rozwoju Obszarów Wiejskich - DG AGRI). Efektem prac grupy roboczej jest raport końcowy, z którego wynika, że większość państw członkowskich przyjęła alternatywną dla opartej na kryterium OECD 
pejskiej występuje wyodrębnienie obszarów wiejskich na podstawie kryterium Eurostatu ${ }^{32}$, odnoszącego się do stopnia urbanizacji. Obszarami wiejskimi są tereny słabo zurbanizowane o gęstości zaludnienia poniżej 100 osób/1 km². Dodatkowo niektóre programy rozwojowe współfinansowane ze środków Unii Europejskiej zaliczają do nich także małe miasta (zwykle liczące do 5 tys. mieszkańców).

W Polsce, zgodnie z definicją Głównego Urzędu Statystycznego opartą na podziale jednostek administracyjnych zastosowanym w Krajowym Rejestrze Urzędowego Podziału Terytorialnego Kraju TERYT ${ }^{33}$, do obszarów wiejskich należą tereny położone poza granicami administracyjnymi miast - obszary gmin wiejskich oraz część wiejska gminy miejsko-wiejskiej (leżąca poza miastem i wyodrębniona przez odrębny identyfikator terytorialny). Ustalenie granic i nadanie gminie bądź miejscowości statusu miasta następuje w drodze rozporządzenia Rady Ministrów ${ }^{34}$. W polskim „Programie rozwoju obszarów wiejskich na lata 2007-2013 (PROW)"35 "za podstawę określenia obszarów wiejskich przyjęto powyższą definicję opartą na administracyjnym podziale kraju, przy czym $\mathrm{z}$ uwagi na powiązania gospodarcze, funkcjonalne i społeczne terenów wiejskich z ośrodkami miejskimi definicja ta wraz z kryterium OECD i Eurostatu traktowana jest jako kontekst i wskaźnik. W rezultacie obszarami wiejskimi w ramach PROW są miejscowości znajdujące się w granicach administracyjnych: gmin wiejskich, gmin wiejsko-miejskich (z wyłączeniem miast liczących powyżej 20 tys. mieszkańców) oraz gmin

definicję obszarów wiejskich - Thematic Working Group 1: Targeting Territorial Specificities and Needs in Rural Development Programmes Approaches to the Definition of Rural Areas in 2007-2013 RDPs, 17.02.2011; www.webgate.ec.europa.eu.

${ }^{32}$ Europejski System Statystyczny utworzony w 1953 r., po przystapieniu Polski do UE prowadzony przez GUS (www.stat.gov.pl).

${ }^{33}$ Krajowy rejestr urzędowy podziału terytorialnego kraju w ramach systemu informacyjnego administracji publicznej prowadzony przez Prezesa Głównego Urzędu Statystycznego na podstawie ustawy z 29 czerwca 1995 r. o statystyce publicznej, t. jedn.: Dz. U. 2012, poz. $591 \mathrm{ze} \mathrm{zm.}$

${ }^{34}$ Art. 4 ust. 1 pkt 2 ustawy z 8 marca 1990 r. o samorządzie gminnym, t.jedn.: Dz. U. 2013, poz. 594 ze zm. Polski porządek prawny zawiera też legalną definicję wsi. Zgodnie z art. 2 pkt 12 ustawy z 29 sierpnia 2003 r. o urzędowych nazwach miejscowości i obiektach fizjograficznych, przez wieś rozumie się ,jednostkę osadniczą o zwartej lub rozproszonej zabudowie i istniejących funkcjach rolniczych lub związanych z nimi usługowych lub turystycznych nieposiadającą praw miejskich lub statusu miasta”, Dz. U. 2003, Nr 166, poz. 1620 ze zm.

${ }_{35}$ Obwieszczenie Ministra Rolnictwa i Rozwoju Wsi z 12 października 2007 r. w sprawie Programu Rozwoju Obszarów Wiejskich na lata 2007-2013, M.P. 2007, Nr 94, poz. 1035, Załącznik, ze zm. 
miejskich (z wyłączeniem miejscowości liczących powyżej 5 tys. mieszkańców).

Pojęcie krajobrazu wiejskiego i jego ochrony ściśle wiąże się także z koncepcja wielofunkcyjnego rolnictwa. Po pierwsze, idea ta daje podstawy do określenia pojęcia obszaru wiejskiego, pozwalającego na przezwyciężenie wyzwań stojących przed europejskim prawem rolnym w kontekście zachowania jego tradycyjnych struktur ${ }^{36}$. Po drugie, wskazuje ona na funkcję krajobrazową działalności rolniczej. Koncepcja wielofunkcyjnego rolnictwa stanowi alternatywę dla tradycyjnych ujęć rolnictwa bazującego na intensywnej produkcji ${ }^{37}$. Nieefektywność tych ostatnich stała się impulsem do przeformułowania perspektywy badawczej i założeń polityki rozwoju rolnictwa. Pojawienie się koncepcji rolnictwa wielofunkcyjnego w Agendzie 21 podczas II Konferencji ONZ w Rio de Janeiro w roku 1992, a następnie przyjęcie jej przez Radę Unii Europejskiej ds. Rolnictwa i Rybołówstwa w 1997 spowodowało szerokie zainteresowanie badaczy tą nową formułą.

W najszerszym ujęciu wielofunkcyjność rolnictwa oznacza, że poza rolą podstawową, którą jest produkcja żywności i włókien, pełni ono również inne dodatkowe funkcje: środowiskowe (zachowanie środowiska i krajobrazu wiejskiego) oraz społeczne (przyczynianie się do żywotności obszarów wiejskich $\mathrm{i}$ ich zrównoważony rozwój) ${ }^{38}$. Ponadto należy zauważyć, że wielofunkcyjność stanowi też immanentną cechę krajobrazu, który - będąc jednostką przestrzenną - może pełnić różne funkcje i cele dla społeczeństwa ${ }^{39}$. Co więcej, koncepcja wielofunkcyjności pozwala na rozszerzenie tradycyjnej perspektywy ekologicznej badań krajobrazowych o zagadnienia społeczno-kulturowe i uwzględnienie zależności między

${ }^{36}$ J. Martinez, Pojęcie "obszar wiejski” jako odpowiedź na wielofunkcyjność przyszłej działalności rolniczej, „Przegląd Prawa Rolnego” 2010, nr 2, s. 49-50.

${ }^{37}$ A. Czyżewski, P. Kułyk, Dobra publiczne w koncepcji wielofunkcyjnego rozwoju rolnictwa, ujęcie teoretyczne i praktyczne, ,Zeszyty Naukowe SGGW w Warszawie - Problemy Rolnictwa Światowego" 11(26), 2011, z. 2, s. 17.

${ }^{38}$ Zob. przegląd literatury i podejść badawczych dotyczących rolnictwa wielofunkcyjnego: H. Renting et al., Exploring Multifunctional Aagriculture. A Review of Conceptual Approaches and Prospects for an Integrative Transitional Framework, „Journal of Environmental Management" 90, 2009, Supplement 2, s. 112-123. Zob. też: Z. Kallas, J. A. Gómez-Limón, M. Arriaza, Are Citizens Willing to Pay for Agricultural Multifunctionality?, „Agricultural Economics” 36, 2007, s. 405-406 i literatura tam powołana.

${ }^{39} \mathrm{H}$. Veire et al., Multifunctional Agriculture and Multifunctional Landscapes - Land Use as an Interface, w: U. Mander, H. Wiggering, K. Helming (red.), Multifunctional Land Use. Meeting Future Demands for Landscape, Goods and Services, Berlin-Heidelberg 2007, s. 93-104. 
charakterem krajobrazu a kontekstem społeczno-ekonomicznym ${ }^{40}$. Połączenie tych dwóch aspektów daje więc całościowe ujęcie problematyki obszarów wiejskich jako systemu wielofunkcyjnego.

W podsumowaniu tej części rozważań należy stwierdzić, że prawne pojęcie krajobrazu funkcjonujące w polskich aktach legislacyjnych oparte jest na koncepcjach fizjonomicznych. W polskim porządku prawnym nie przyjęto legalnej definicji krajobrazu, stanowi on jednak termin prawny występujący w wielu aktach normatywnych, często jednak w różnych znaczeniach, odwołujących się do poszczególnych rodzajów krajobrazu. Odmienne, szersze jego rozumienie zawarto w Europejskiej konwencji krajobrazowej. Krajobraz jest w niej ujmowany całościowo i dynamicznie oraz w ścisłej relacji z człowiekiem. Wydaje się, że właśnie takie pojęcie powinno stanowić podstawę współczesnych ujęć w płaszczyźnie normatywnej i badawczej.

Wyodrębnienie krajobrazu wiejskiego opiera się następnie na ustaleniach dotyczących obszaru wiejskiego. Jednak także ten termin napotyka trudności definicyjne. Wynikają one nie tylko z przyjmowania różnych kryteriów kwalifikacyjnych, lecz także z jego wieloaspektowości i interdyscyplinarności. Powiązanie pojęcia obszarów wiejskich z koncepcją wielofunkcyjnego rolnictwa wyznacza nowe perspektywy badawcze w zakresie badań krajobrazu wiejskiego i jego ochrony, a ponadto odpowiada holistycznemu pojmowania krajobrazu przyjętemu w Europejskiej konwencji krajobrazowej. Wydaje się, że formułowanie pojęcia krajobrazu wiejskiego na potrzeby badań prawniczych powinno opierać się na delimitacji obszarów wiejskich zgodnie z definicją Głównego Urzędu Statystycznego, ze względu na jego obiektywny charakter i prawne przesłanki przyjętego kryterium wyróżnienia. Jednocześnie należy jednak zastrzec konieczność elastyczności podejścia badawczego i uwzględnienia wspomnianej powyżej wieloaspektowości tego pojęcia.

3. Mimo że prawna ochrona krajobrazu w Polsce posiada niemal stuletnią tradycję i podlegała ciagłemu rozwojowi w tym czasie ${ }^{41}$, to nadal brak $\mathrm{w}$ ustawodawstwie prawnym rozwiązań systemowych. Podstawy normatywne ochrony krajobrazu rozproszone są w wielu aktach. Konstytucja RP z 2 kwietnia 1997 r. nie zawiera bezpośredniego odniesienia do

\footnotetext{
${ }^{40}$ D. Wascher, B. Pedroli, op. cit., s. 24.

${ }^{41} \mathrm{~W}$ kwestii powstania i rozwoju koncepcji ochrony krajobrazu w prawie polskim zob. H. Olbrycht, op. cit., s. 98-105.
} 
krajobrazu. Zagadnienie to regulowane jest przez zapisy o ochronie środowiska i zrównoważonym rozwoju ${ }^{42}$. Ta ogólna zasada konstytucyjna znajduje następnie rozwinięcie w aktach ustawowych i podustawowych odnoszących się do trzech aspektów krajobrazu: przyrodniczego, kulturowego i wizualnego.

Pierwsza grupa przepisów mającą na celu ochronę krajobrazów cennych zawarta jest $\mathrm{w}$ prawie ochrony przyrody. Ustawa o ochronie przyrody wskazuje krajobraz jako składnik przyrody podlegający ochronie, czyli zachowaniu, zrównoważonemu użytkowaniu oraz odnawianiu (art. 2 ustawy). W tym celu przewidziano tworzenie różnych obszarów i obiektów chronionych wskazanych w art. 6 ustawy. Większość z nich to obszary wielkoprzestrzenne, składające się na układ obszarów chronionych powiązanych wzajemnie za pomocą korytarzy ekologicznych. We wszystkich tych formach ochrony występuje w mniejszym lub większym nasileniu problematyka krajobrazu, różna jest też ich skuteczność ${ }^{43}$. Swoistym instrumentem ochronnym jest natomiast park gminny regulowany w art. 81 ustawy o ochronie przyrody ${ }^{44}$.

Formy ochrony krajobrazu kulturowego przewidziano w ustawie z 23 lipca 2003 r. o ochronie zabytków i opiece nad zabytkami ${ }^{45}$ i należą do nich: wpis do rejestru zabytków, uznanie za pomnik historii, utworzenie parku kulturowego oraz ustalenie ochrony w miejscowym planie zagospodarowania przestrzennego albo w decyzji lokalizacyjnej (art. 7 ustawy).

Kompleksową regulacją dotyczącą całokształtu problematyki środowiska (w tym krajobrazu) zawierają też akty normatywne z zakresu prawa ochrony środowiska. W ustawie z 2001 r. - Prawo ochrony środowiska ochrona jest rozumiana szeroko - jako zarządzanie krajobrazem, obejmuje bowiem racjonalne kształtowanie i gospodarowanie zasobami zgodnie

${ }^{42} \mathrm{~W}$ kwestii ochrony środowiska w Konstytucji Rzeczypospolitej Polskiej zob. B. Rakoczy, Ograniczenie praw $i$ wolności jednostki ze względu na ochronę środowiska w Konstytucji Rzeczpospolitej Polskiej, Toruń 2006, passim.

${ }^{43}$ Mało skutecznym narzędziem ochrony krajobrazu okazały się w praktyce obszary chronionego krajobrazu. Zob. Ł. Puszyński, Ochrona krajobrazu naturalnego jako zadanie samorzqdu terytorialnego, „Casus” 2011, nr 60, s. 54.

${ }^{44}$ Zgodnie z art. 81 ustawy o ochronie przyrody ,teren położony poza obrębem miast i wsi o zwartej zabudowie, pokryty drzewostanem i nieobjęty ochroną na podstawie ustawy z 23 lipca 2003 r. o ochronie zabytków i opiece nad zabytkami, rada gminy może uznać za park gminny, jeżeli stanowi własność gminy, a jeżeli stanowi własność innego podmiotu - za zgodą właściciela".

${ }^{45}$ Dz. U. 2003, Nr 162, poz. 1568 ze zm. 
z zasadą zrównoważonego rozwoju oraz działania restytucyjne - przywracanie elementów przyrodniczych do stanu właściwego (art. 3 pkt 13 Prawa ochrony środowiska). Akt ten przewiduje metodę ochrony w formie polityki ekologicznej państwa oraz wojewódzkich, powiatowych i gminnych programów ochrony środowiska, a także zawiera wytyczne dotyczące zagospodarowania przestrzennego. Natomiast odrębnie regulowana jest procedura oceny oddziaływania na środowisko ${ }^{46}$.

Ochronie krajobrazu służy także prawo planowania przestrzennego i prawo budowlane. Ustawa z 27 marca 2003 r. o planowaniu i zagospodarowaniu przestrzennym ${ }^{47}$, określając zasady kształtowania polityki przestrzennej i regulując postępowanie w zakresie przeznaczania terenów na określone cele oraz ustalania zasad ich zagospodarowania, stanowi podstawowy akt dotyczący gospodarowania przestrzenią w Polsce ${ }^{48}$. Przepisy prawa budowlanego dla ochrony krajobrazu mają natomiast charakter wtórny w stosunku do norm prawa zagospodarowania przestrzennego, co wynika z kolejności poszczególnych etapów i faz procesu inwestycyjno-budowlanego.

Na podstawie analizy polskich aktów prawnych można stwierdzić, że brakuje spójnych rozwiązań systemowych w zakresie ochrony krajobrazu. Przyjmuje się różne pojęcia krajobrazu, choć zbliżone, a metody jego ochrony w poszczególnych aktach prawnych nie są wzajemnie skoordynowane. Powoduje to nieskuteczność instrumentów wdrażania polityki krajobrazowej, a także postępujące obniżenie jakości krajobrazu w Polsce. Mała efektywność ochrony, a nawet konflikty i sprzeczności planowanych zadań ochronnych, mają źródło w niespójności systemu oraz braku szerszej perspektywy teoretycznej i metodologicznej ${ }^{49}$.

Negatywny wpływ na stan krajobrazu ma przede wszystkim nieprawidłowe funkcjonowanie prawnego systemu planowania przestrzennego. W szczególności można wymienić tu następujące negatywne zjawiska: brak powiązania dokumentów planistycznych różnych szczebli, fakulta-

${ }^{46}$ Ustawa z 3 października 2008 r. o udostępnianiu informacji o środowisku jego ochronie, udziale społeczeństwa w ochronie środowiska oraz o ocenach oddziaływania na środowisko, t.jedn.: Dz. U. 2013, poz. 1235 ze zm.

${ }^{47}$ T.jedn.: Dz. U. 2012, poz. 647 ze zm.

${ }^{48} \mathrm{~W}$ sprawie ochrony krajobrazu w prawie zagospodarowania przestrzennego i jej prawnych granic zob. T. Bąkowski, op. cit., s. 31-44.

${ }^{49}$ J. Solon, Postulaty dotyczqce zasad ochrony krajobrazu, w: Ochrona krajobrazu przyrodniczego i kulturowego a rozwój cywilizacyjny. Biuletyn Forum Debaty Publicznej „Twórczość, Dziedzictwo Kulturowe i Przyrodnicze Bogactwem Polski” 2011, nr 3, www.prezydent.pl, s. 85 . 
tywność uchwalania miejscowych planów zagospodarowania przestrzennego, a w konsekwencji - ich rozdrobnienie i nikłe pokrycie powierzchni kraju, oparcie gospodarowania przestrzenią na decyzjach lokalizacyjnych $^{50}$. Również system instrumentów ochronnych wynikający z regulacji prawa ochrony przyrody w praktyce okazuje się niewydolny. Na terenach objętych przewidzianymi prawem formami ochrony przyrody wprowadzane są zakazy określone ustawą. Jednakże dowolność w ich wyborze, a także brak możliwości pozytywnego wpływania na kształtowanie krajobrazu powodują nieskuteczność ochrony i nieadekwatność do rzeczywistych zagrożeń chronionych wartości ${ }^{51}$.

4. Ochronie krajobrazu wiejskiego służą wyżej wymienione instrumenty prawne. Ponadto kwestia ta regulowana jest $w$ aktach prawnych bezpośrednio związanych z rolnictwem - np. w ustawie z 3 lutego $1995 \mathrm{r}$. o ochronie gruntów rolnych i leśnych ${ }^{52}$, w której jako formę ochrony gruntów wskazano ograniczanie zmian naturalnego ukształtowania powierzchni ziemi. Ze względu na immanentny związek rolnictwa ze środowiskiem problematyka ochrony krajobrazu wiejskiego nabiera szczególnego znaczenia. Ponadto pojawia się tu szereg zagadnień swoistych. Poniżej zostaną wskazane niektóre $\mathrm{z}$ nich.

$\mathrm{Na}$ terenach wiejskich występuje szczególnie dużo cennych ekosystemów naturalnych, z którymi związane są specjalne formy ochrony, określone przede wszystkim w ustawie o ochronie przyrody. Rodzi to jednak niebezpieczeństwo niewystarczającej, fragmentarycznej ochrony - kwestie krajobrazu roztopione zostają w zagadnieniach ochrony poszczególnych elementów środowiska ${ }^{53}$.

Ochrona krajobrazu jest współcześnie istotnym elementem polityki rolnej. Jak wskazywano powyżej, idea wielofunkcyjnego prośrodowiskowego rolnictwa, będącego podstawą zrównoważonego rozwoju regionu, jest wyrazem nowej koncepcji ochrony środowiska (w tym krajobrazu) na terenach wiejskich w Unii Europejskiej. Poprawa stanu środowiska stanowić ma impuls do wszechstronnego rozwoju obszaru przez stymulowanie zrównoważonego gospodarowania, właściwego użytkowania gruntów

${ }^{50}$ Zob. np. Z. Niewiadomski (red.), Prawna regulacja procesu inwestycyjno-budowlanego: uwarunkowania, bariery, perspektywy, Warszawa 2009, passim.

${ }^{51}$ P. Otawski, Krajobraz - ochrona prawna, stan obecny, perspektywy, w: Ochrona krajobrazu przyrodniczego..., s. 33.

${ }^{52}$ T.jedn.: Dz. U. 2013, poz. 1205 ze zm.

${ }^{53}$ M. A. Król, op. cit., s. 66. 
i wód zgodnego $\mathrm{z}$ dobrą praktyką rolniczą w obrębie gospodarstwa ${ }^{54}$. Koncepcja ta wpływa też na treść prawnych instrumentów wspierania rozwoju obszarów wiejskich przez Unię Europejską.

Należy podkreślić, że problematyka ochrony krajobrazu stanowi jeden z celów szczegółowych (obszarów fokusowych) wchodzących w zakres czwartego priorytetu polityki rozwoju obszarów wiejskich na lata 20142020 (odtwarzanie, ochrona i wzmacnianie ekosystemów zależnych od rolnictwa i leśnictwa) ${ }^{55}$. Zagadnienia te zajmują też istotne miejsce w polskim Projekcie Programu Rozwoju Obszarów Wiejskich 2014-2020 (PROW 2014-2020), w którym podejmowane są nie tylko w kontekście działań rolno-środowiskowo-klimatycznych czy scalania gruntów, lecz również w ramach odnowy miejscowości na obszarach wiejskich. Warto też zaznaczyć, że właśnie swoistość rolnictwa polskiego na tle innych państw Unii Europejskiej w aspekcie problematyki krajobrazowej, środowiskowej i bioróżnorodności doskonale wpisuje się $\mathrm{w}$ nowe założenia Wspólnej Polityki Rolnej ${ }^{56}$.

Planowanie przestrzenne jest jedną z podstawowych form ochrony walorów krajobrazowych. W ujęciu modelowym instrumenty planowania miejscowego opierające się na planach ochrony kształtują krajobraz, również w odniesieniu do obszarów chronionych i ich otoczenia. Planowanie przestrzenne terenów wiejskich wykazuje jednak szereg swoistych cech, co w obliczu niewydolności systemu planowania przestrzennego w Polsce rodzi szczególne problemy, znajdujące odzwierciedlenie w kondycji krajobrazu obszarów wiejskich. Należy do nich chaotyczna i oderwana od kontekstu zabudowa mieszkaniowa, zwłaszcza na urbanizujących się tere-

${ }^{54}$ T. Kurowska, Wlasność gruntowa a planowanie przestrzenne $w$ dorobku naukowym Profesora Waleriana Pańki, „Studia Iuridica Agraria” 10, 2012, s. 22.

${ }^{55}$ Polityka wiejska Unii Europejskiej na lata 2014-2020 została wyznaczona w komunikacie Komisji z 18 listopada 2010 r. do Parlamentu Europejskiego, Rady, Europejskiego Komitetu Ekonomiczno-Społecznego i Komitetu Regionów pt. „Wspólna polityka rolna do 2020: sprostać wymaganiom przyszłości związanym z żywnością, zasobami naturalnymi i aspektami terytorialnymi” (COM [2010] 672 wersja ostateczna) oraz w Komunikacie Komisji pt. „Europa 2020. Strategia na rzecz inteligentnego i zrównoważonego rozwoju sprzyjającego włączeniu społecznemu" (COM [2010] 2020). Założenia tej strategii znalazły następnie rozwinięcie w pakiecie aktów legislacyjnych dotyczących przede wszystkim wspierania rozwoju obszarów wiejskich, finansowania Wspólnej Polityki Rolnej oraz funduszy strukturalnych. Szerzej na ten temat zob. E. Tomkiewicz, M. Bocheński, Polityka rozwoju obszarów wiejskich w perspektywie 2014-2020 w kontekście nowych wyzwań, „Studia Iuridica Agraria” 10, 2012, s. 239-250.

${ }^{56}$ R. Budzinowski, O przyszłości Wspólnej Polityki Rolnej - uwagi z perspektywy Polski, w: J. Bieluk et al. (red.), Z zagadnień prawa rolnego, cywilnego i samorzadu terytorialnego. Księga jubileuszowa profesora Stanisława Prutisa, Białystok 2012, s. 55-56. 
nach wiejskich. Ponadto zmniejszenie się powierzchni użytkowanych rolniczo na skutek polityki ekstensyfikacji produkcji rolnej prowadzi do fragmentaryzacji krajobrazu i naruszenia jego struktury ekologicznej ${ }^{57}$.

Tymczasem polska regulacja dotycząca planowania przestrzennego nie odpowiada na powyższe problemy. Ponadto ze względu na swój raczej urbanistyczny charakter ma ograniczone zastosowanie w odniesieniu do gruntów rolnych położonych na obszarach wiejskich ${ }^{58}$. Polski model planowania przestrzennego nie jest adekwatny do współczesnych potrzeb rozwoju obszarów wiejskich, gdyż nie uwzględnia ich wielofunkcyjności, koncentruje się bowiem na zagadnieniach związanych z rolniczą przestrzenią produkcyjną ${ }^{59}$. Dodatkowo problemem jest brak spójności i skoordynowania między metodami identyfikacji i oceny krajobrazu a instrumentami planistycznymi. Powyższe tendencje rozwojowe wraz z nieadekwatnością do problematyki wiejskiej oraz obserwowaną niewydolnością instrumentów planowania przestrzennego $\mathrm{w}$ widoczny sposób wpływają negatywnie na jakość krajobrazu wiejskiego w Polsce.

5. Przedstawiony przez Prezydenta Rzeczypospolitej Polskiej projekt ustawy o zmianie niektórych ustaw w związku ze wzmocnieniem narzędzi ochrony krajobrazu ${ }^{60}$ jest w założeniu wnioskodawców odpowiedzią na postępującą degradację krajobrazu polskiego oraz brak rządowych działań legislacyjnych. Ponadto - mimo że jeden z głównych celów inicjatywy stanowi implementacja do polskiego porządku prawnego Europejskiej konwencji krajobrazowej - to jednak, jak podkreślono w uzasadnieniu, ustawa nie aspiruje do kompleksowego wprowadzenia jej rozwiązań, lecz zakłada minimalny zakres zmian przy jednoczesnym uzyskaniu znacznego poziomu ochrony krajobrazu ${ }^{61}$.

${ }^{57}$ E. Raszeja, Ochrona..., s. 29.

${ }^{58}$ T. Kurowska, op. cit., s. 26.

${ }^{59} \mathrm{~S}$. Prutis, Instrumenty planowania przestrzennego $w$ rolnictwie. Założenia modelowe a rzeczywistość, „Studia Iuridica Agraria” 10, 2012, s. 40-41.

${ }^{60}$ Druk nr 1525. Projekt wpłynął do Sejmu 1 lipca 2013 r., po pierwszym czytaniu na posiedzeniu Sejmu został skierowany do Komisji Infrastruktury, Komisji Kultury i Środków Przekazu oraz Komisji Samorządu Terytorialnego i Polityki Regionalnej, z zaleceniem zasięgnięcia opinii Komisji Ochrony Środowiska, Zasobów Naturalnych i Leśnictwa. 12 września 2013 r. ukonstytuowała się podkomisja nadzwyczajna do rozpatrzenia przedmiotowego prezydenckiego projektu ustawy, która obecnie prowadzi prace w tym temacie (stan na 12 kwietnia $2014 \mathrm{r}$.) (dalej jako: ustawa krajobrazowa).

${ }^{61}$ Uzasadnienie projektu ustawy o zmianie niektórych ustaw w związku ze wzmocnieniem narzędzi ochrony krajobrazu, s. 7. 
Projekt przewiduje przede wszystkim wprowadzenie do przepisów ustawy - Prawo ochrony środowiska legalnej definicji krajobrazu opartej na znaczeniu tego terminu w Europejskiej konwencji krajobrazowej. Zgodnie z tą propozycją przez krajobraz rozumie się ,postrzeganą przez ludzi przestrzeń, zawierającą elementy przyrodnicze lub wytwory cywilizacji, ukształtowaną w wyniku działania czynników naturalnych lub działalności człowieka" ${ }^{62}$. Kolejnym istotnym nowym terminem ustawowym jest dominanta krajobrazowa, definiowana jako: „obiekt o wiodącym oddziaływaniu wizualnym w krajobrazie"63. Ustawa krajobrazowa zakłada przeprowadzenie przez samorząd województw powszechnej identyfikacji i waloryzacji krajobrazów w formie audytu krajobrazowego oraz wprowadzenie nowych instrumentów ochrony krajobrazu: urbanistycznych zasad ochrony krajobrazu, obostrzenia w procedurze lokalizacji dominant krajobrazowych, rozszerzenia zakresu ocen oddziaływania na środowisko oraz nowych regulacji odnoszących się do lokalizowania reklam. Projekt przewiduje też rozszerzenie przepisów przeciwdziałających utrzymywaniu obiektów oszpecających otoczenie oraz dokonanie zmian porządkowych dotyczących parków krajobrazowych i obszarów chronionego krajobrazu.

Ustosunkowując się do planowanych uregulowań zawartych w projekcie „ustawy krajobrazowej”, należy przede wszystkim pozytywnie ocenić samo podjęcie problematyki ochrony krajobrazu, jako kwestii znaczącej i pilnej. Ponadto istotne jest wprowadzenie do polskiego porządku prawnego definicji krajobrazu opartej na regulacji Europejskiej konwencji krajobrazowej. Watpliwości budzi natomiast koncepcja ochrony krajobrazu, jaką można wydedukować z przewidzianych projektem zmian.

Po pierwsze, powstaje pytanie, czy celowe jest wprowadzenie zestawu nowych instrumentów prawnych ochronnych, tym bardziej że analiza ich konstrukcji prawnej wskazuje, iż wkraczają one w zakres przedmiotowy narzędzi już istniejących. Przykładowo uwarunkowania przyrodnicze i kulturowe są elementem opracowań ekofizjograficznych, wojewódzkich planów zagospodarowania przestrzennego. Na szczeblu województwa istnieją też programy opieki nad zabytkami. Trudno zatem znaleźć uzasadnienie sporządzania kolejnych dokumentów: audytu krajobrazowego i urbanistycznych zasad ochrony krajobrazu. Nie jest też jasne, co miałoby gwarantować wyższą skuteczność tych instrumentów w ochronie krajo-

\footnotetext{
${ }^{62}$ Art. 6 pkt 1 ustawy krajobrazowej.

${ }^{63}$ Art. 9 pkt 2 lit. d ustawy krajobrazowej.
} 
brazu i jak układa się relacja między nowymi i funkcjonującymi już dokumentami.

Po drugie, wątpliwości budzi usytuowanie wprowadzanych zmian. Dotyczy to umiejscowienia urbanistycznych zasad ochrony krajobrazu w ustawie o ochronie przyrody, gdy tymczasem ich charakter wskazuje na powiązanie tematyczne $\mathrm{z}$ ładem przestrzennym, co przesądza o ich przynależności do problematyki planowania i zagospodarowania przestrzennego. Jest to szczególnie istotne w obliczu oczekiwanej i opracowywanej już gruntownej rekonstrukcji prawnego systemu gospodarki przestrzennej w Polsce. Ponadto usytuowanie tego dokumentu na poziomie województwa budzi wątpliwości w kontekście naruszenia samodzielności planistycznej gminy i konstytucyjnej zasady pomocniczości.

Warty odnotowania jest wniosek płynący z analizy zapisów „ustawy krajobrazowej”, że nie przystają one do specyfiki zagadnień ochrony krajobrazu obszarów wiejskich, co niestety wpisuje się w silną tendencję zdeterminowania problematyki ochrony krajobrazu spojrzeniem urbanistycznym, obecną zarówno w normatywnym, jak i naukowym ujęciu ochrony krajobrazu w Polsce. Jako przykład można tu chociażby wskazać ustawowy termin „urbanistyczne zasady ochrony krajobrazu”. Tymczasem można uznać, iż przedmiotem ustawy są w równym stopniu, jeśli nie nawet w przeważającej części, zagadnienia krajobrazowe dotyczące obszarów wiejskich, a zatem ruralistycznego wymiaru ochrony krajobrazu.

Jednym $\mathrm{z}$ budzących najwięcej emocji elementem projektu w zakresie problematyki ochrony krajobrazu wiejskiego jest regulacja dotycząca dominant krajobrazowych $\mathrm{w}$ kontekście rozwoju energetyki wiatrowej. Zgodnie $\mathrm{z}$ definicją ustawową oraz uzasadnieniem ustawy ${ }^{64}$ wieże $\mathrm{z}$ turbinami wiatrowymi, co do zasady stanowić będą dominanty krajobrazowe. Jednym z celów omawianego aktu jest też uniemożliwienie lokalizowania tych obiektów na terenach objętych ochroną ze względu na walory krajobrazowe. Jak argumentuja przedstawiciele branży wiatrakowej, projektowa ustawa spowodowałaby ogromne spowolnienie rozwoju tego typu energetyki w Polsce ${ }^{65}$. Problem lokalizowania wież z turbinami wiatrowymi w kontekście ochrony krajobrazu jest niewątpliwie zagadnieniem trudnym i ze swej natury konfliktowym. Ponadto są to obiekty o formie zdeterminowanej kwestiami technicznymi i efektywnością, nie ma więc

${ }^{64}$ Uzasadnienie ustawy krajobrazowej, s. 27.

${ }^{65}$ Zob. np. Stanowisko Polskiego Stowarzyszenia Energetyki Wiatrowej do projektu ustawy o zmianie niektórych ustaw w związku ze wzmocnieniem narzędzi ochrony krajobrazu z 21 maja 2013 r., http://www.psew.pl. 
w ich przypadku zbyt dużych możliwości zharmonizowania z otoczeniem, w zasadzie poza dostosowaniem wysokości siłowników i ich liczby. Wydaje się zatem, że słuszne jest założenie uniemożliwienia lokalizowania tych obiektów w miejscach stwarzających możliwość ich oddziaływania na obszary objęte ochrona. $Z$ drugiej strony definicja dominanty przyjęta $\mathrm{w}$ ustawie nie przystaje do tego, jak funkcjonują w krajobrazie elektrownie wiatrowe, szczególnie ich zespoły, co może utrudniać właściwą, prewencyjną ochronę krajobrazu w przypadku tych inwestycji.

6. Podsumowując rozważania, można stwierdzić, że wyznaczenie prawnego pojęcia krajobrazu wiejskiego jest zadaniem trudnym ze względu na jego wieloaspektowość i interdyscyplinarność, a także brak definicji legalnej krajobrazu i niespójności przepisów w tym zakresie. Założenia obecnego systemu prawnego nie przystają w pełni do współczesnego ujęcia tego zagadnienia ani w prawie międzynarodowym z Europejską konwencją krajobrazową na czele, ani w nauce. W szczególności brakuje kompleksowego i wielofunkcyjnego ujmowania krajobrazu jako procesu i syntezy środowiska przyrodniczego, kulturowego i wizualnego, co nie pozwala na całościowe, zintegrowane podejście do jego ochrony i kształtowania. Tymczasem takie właśnie rozumienie, wywodzące się z uregulowań Konwencji, w połączeniu z delimitacją obszarów wiejskich w oparciu o kryterium statystyczne, pozwala budować pojęcie krajobrazu wiejskiego, które będzie użyteczne z punktu widzenia jego ochrony prawnej.

Przeprowadzone rozważania prowadzą ponadto do wniosku, że polskie rozwiązania legislacyjne nie tworzą spójnego i skutecznego systemu ochrony krajobrazu terenów wiejskich. Przyczyną tego jest przede wszystkim rozproszenie przepisów, często wzajemnie nieskoordynowanych, ogólna niewydolność regulacji prawnej planowania przestrzennego oraz oparcie na przestarzałej formule ochrony zachowawczej i restytucyjnej zamiast na zintegrowanym, dynamicznym i zrównoważonym zarządzaniu krajobrazem. Ponadto podejście urbanistyczne, zarówno w wymiarze normatywnym, jak i badawczym, nie odpowiada roli, jaką pełnią obszary wiejskie w tym aspekcie. Tymczasem kwestie te coraz szerzej są obecne w polityce rolnej Unii Europejskiej.

Zatem istnieje konieczność podjęcia działań mających na celu przeformułowanie systemu i dostosowanie do współczesnych koncepcji, opartych w szczególności na zrównoważonym rozwoju, zintegrowanej ochronie aktywnej oraz wielofunkcyjności rolnictwa i krajobrazu. Podjęte inicjatywy ustawodawcze w tym względzie, mimo że uzasadnione i pożą- 
dane, ze względu na swój doraźny i wyrywkowy charakter nie mają szans spełnienia tych postulatów. Wydaje się zatem, że przyjęcie ich nie wpłynie istotnie na poprawę jakości krajobrazu wiejskiego w Polsce.

\title{
LEGAL ASPECTS OF LANDSCAPE PROTECTION IN RURAL AREAS
}

\author{
Sum mary
}

The aim of this paper is an attempt to determine the extent to which a normative regulation helps effective protection of rural landscape. This goal requires first of all a legal definition of a rural landscape, keeping in mind the draft landscape law which uses the term 'landscape' but fails to provide its legal definition. What is more, the term can be found in a number of legislative acts providing for and referring to different types of landscape.

The author thus concludes that the assumptions existing in the legal system currently binding in Poland are not fully compatible with the contemporary approach to landscape protection in international law and science. What is more, the existing legal solutions are neither satisfactorily coherent or efficient to effectively protect the landscape in rural areas, while the legislative initiatives so far undertaken have been of a stop-gap and interim character, not capable of adequately harmonising the existing legal system with modern concepts based on sustainable development and integrated active protection and multifunctional agriculture.

\section{SULLE QUESTIONI GIURIDICHE DELLA TUTELA DEL PAESAGGIO NELLE ZONE RURALI}

\author{
Riassunto
}

L'obiettivo dello studio è quello di tentare di rispondere alla domanda di come la regolamentazione normativa garantisca una efficace tutela del paesaggio. Il raggiungimento di questo obiettivo richiede di determinare il concetto giuridico di paesaggio rurale e di prendere in considerazione il progetto della c.d. „legge sul paesaggio”. Il legislatore polacco ricorre al termine ,paesaggio”, ma non fornisce la sua definizione legale. Esso è presente in molti atti legislativi, ma con diverse accezioni e in riferimento ai singoli tipi di paesaggio.

In conclusione, l'autrice afferma che i presupposti dell'attuale sistema giuridico non corrispondono pienamente all'attuale modo di inquadrare la tutela del paesaggio nel diritto internazionale e nella scienza. Inoltre le soluzioni legislative non formano un sistema coerente ed efficace per tutelare il paesaggio nelle zone rurali. Le iniziative legislative intraprese, visto il loro carattere ad hoc e selettivo, non sono in grado di far adattare il sistema giuridico alle attuali concezioni basate sullo sviluppo sostenibile, sulla protezione integrata attiva e sulla multifunzionalità dell'agricoltura. 